\title{
Karel Černý - Ludmila Hlaváčková (edd.) a kolektiv autorů, Biografický slovník 1. lékařské fakulty Univerzity Karlovy 1945-2008, I. díl (A-L)
}

Nakladatelství Karolinum, Praha 2018, 191 stran. ISBN 978-80-246-3801-0

Důvody, které vedly pracovníky Ústavu dějin lékařství a cizích jazyků 1 . LF UK ke zpracování tak rozsáhlého a složitého projektu, z několika důvodů neobyčejně užitečného, ale $\mathrm{z}$ jiných přesto nevděčného, vysvětlují jeho editoři v předmluvě. Biografické slovníky obecně patří $\mathrm{k}$ základním pomůckám badatelů v jednotlivých historiografických disciplínách a platí to pochopitelně i pro historiky medicíny. ${ }^{1} \mathrm{~V}$ př́padě ÚDL CJ je příprava biografických slovníků již osvědčenou tradicí. Dosud vydané slovníky pražských lékařských fakult (včetně německé) pro období od založení univerzity do roku 1939 (1945) patři i v zahraničí k oceňovaným pomůckám. Jejich pokračování v předložené (I. díl) i připravované podobě (II. díl) nejenom završí tento unikátní projekt, ale zařadí se zcela do kontextu dalších publikací ústavu, zabývajícího se systematicky dějinami fakulty, at' už jako jejich doplněk nebo východisko dalšího bádání. Jako další publikace zabývající se dějinami instituce bude slovník plnit rovněž významnou úlohu při formování korporátní identity a institucionální paměti fakulty, respektive univerzity.

O tom, jak obrovský úkol stál před autory slovníku, informují rovněž autoři předmluvy. „Masifikace“ univerzitního vzdělání, charakteristická pro evropské univerzity po druhé světové válce, se projevila nejenom v nárůstu počtu studentů, ale také učitelů. Z toho vyplynulo první koncepční omezení autorů, kteří museli sáhnout k jinému vymezení osob, které je možné podchytit a alespoň na základní úrovni efektivně a kvalitně zpracovat, než tomu bylo u slovníků pro starší období. Na základě předběžných analýz museli pochopitelně rezignovat na zahrnutí všech (odhadem více než 4000) učitelských zaměstnanců fakulty, včetně asistentů, a omezit záběr „,pouze“ na habilitované pracovníky (kolem 1000). Toto omezení oproti předchozím svazkům slovníků je ovšem zcela pochopitelné a odůvodnitelné. Vážnějším ohrožením celého projektu byla legislativa omezující badatelům o soudobých dějinách př́stup $\mathrm{k}$ řadě relevantních primárních pramenů. Přísná ustanovení archivního zákona a zákona na ochranu osobních údajů výrazně limitovala heuristickou základnu a autoři museli své rešerše zaměřit na úřední tisky (seznamy osob, ústavů a přednášek fakulty i celé UK) a sekundární literaturu. Třetí oblastí limitující práce na slovníku byl systém financování a hodnocení vědecké práce a produkce. Vzhledem k tomu, že biografické slovníky jsou často neprávem přezírány jako „metodologicky značně konzervativní“ výstupy, jsou omezené také možnosti, jak velké týmy potřebné pro jejich systematické a dlouhodobé zpracování organizovat a financovat nad rámec úkolů, zdrojů a časových možností relativně malého pracoviště. V př́padě ÚDL CJ se zásluhou vedení ústavu, fakulty i univerzity sešly dvě št’astné okolnosti, jejichž synergický efekt dovolil přistoupit i k takto rozsáhlému a časově náročnému projektu. K financování bylo možné použít prostředky rozdělované v rámci programu Prvouk a na vlastní práci se mohli podílet studenti doktorského studia.

Výsledek je i přes uvedená omezení oslňující a je třeba zdůraznit zejména následující charakteristiky:

1 Viz např́íklad kapitola Biographische Nachschlagewerke in der Medizin, in: Wolfgang U. ECKART - Robert JüTTE, Medizingeschichte. Eine Einführung, Köln - Weimar - Wien 2007, s. 93-94. 
- předložený svazek představuje zhruba 500 biogramů, které jsou pochopitelně zařazeny na základě jasně stanovených kritérí, jednotně strukturovány a v závislosti na významu jednotlivých osob přiměřeně rozsáhlé;

- i na základě omezeného okruhu pramenů bylo možné zachytit $\mathrm{v}$ základních rysech průběh kariéry sledovaných osobností, přičemž, jak autoři zdůrazňují, v popředí stojí jejich zaměstnání na 1 . LF a jejích předchůdkyních;

- na základě odborné literatury jsou u hesel uvedeny stručné hodnotící charakteristiky;

- jako původně nezamýšlený bonus vznikl velmi užitečný závěrečný přehled Pracoviště pražské lékařské fakulty (nyní 1. LF UK) v letech 1945-2008 (s. 163-191);

- svazek doplňují nezbytné pomůcky jako seznam zkratek, pramenů a literatury.

Obsah jednotlivých biogramů není možné faktograficky kontrolovat, důležité je, že jsou zpracovány podle jednotných kritérií a na základě stejného korpusu pramenů a literatury. Celkově je dílo koncepčně promyšlené a vyvážené, spolehlivě zpracované a vysoce užitečné. Lze jen doufat, že druhý díl vyjde co nejrychleji.

Petr Svobodný

doi: $10.14712 / 23365730.2019 .14$ 